\title{
KAPASITAS KELEMBAGAAN DALAM PEMBERDAYAAN MASYARAKAT PETANI PENERIMA SERTIFIKAT TANAH MELALUI PROGRAM KREDIT USAHA TANI DI KABUPATEN BUTON
}

\author{
Institutional Capacity In Empowering Farming Communities Receiving Land Certificates Through Farming \\ Business Credit Program In Buton Regency
}

\section{Zainul Abidin* \\ *I Universitas Dayanu \\ Ikhsanuddin, Baubau}

email:

zainulabidin180@gmail.com

\section{Kata Kunci:}

Kapasitas Kelembagaan

Pemberdayaan

Sertifikat Tanah

Kredit Usaha Tani

\section{Keywords:}

Institutional Capacity

Empowerment

Land Certificate

Farm Business Credit

\section{Accepted}

Juli 202

Published

October 2021

\begin{abstract}
Abstrak
Penelitian ini bertujuan untuk mendeskripsikan dan menguraikan kapasitas kelembagaan pemerintah daerah dalam memberdayakan masyarakat petani penerima sertipikat tanah melalui program Kredit Usaha Tani di Kecamatan Lasalimu Kabupaten Buton. Metode penelitian ini menggunakan deskriptif kualitatif. Data didapatkan melalui wawancara, observasi dan dokumentasi. Data dianalisis dengan menyiapkan data dan mengorganisir data, mereduksi data dan menyajikan data. Hasil penelitian menunjukkan kapasitas kelembagan dalam pemberdayaan masyarakat petani belum terorganisir dengan baik dan belum terjalin kerjasama yang terintegrasi antara actor atau stakeholder yang terlibat. Kelembagaan terkait masih berjalan sendiri-sendiri dalam program pemberdayaan masyarakat tani. Sehingga masalah ketidakberdayaan masih melekat pada sebahagian petani. Diperlukan evaluasi kapasitas kelembagan dalam pemberdayaan masyarakat agar tidak terjadi egosektoral.
\end{abstract}

\begin{abstract}
This study aims to describe and describe the institutional capacity of local government in empowering farming communities who receive land certificates through the Farmer Business Credit program in Lasalimu District, Buton Regency. This research method uses descriptive qualitative. Data obtained through interviews, observation and documentation. Data is analyzed by preparing data and organizing data, reducing data and presenting data. The results of the study indicate that the institutional capacity in empowering farming communities has not been well organized and there has not been an integrated collaboration between the actors or stakeholders involved. The related institutions are still running independently in the farmer community empowerment program. So that the problem of powerlessness is still attached to some farmers. It is necessary to evaluate institutional capacity in community empowerment so that there is no ego-sectoral occurrence.
\end{abstract}




\section{PENDAHULUAN}

Melalui Kredit Usaha Tani atau Kredit Usaha Rakyat (KUR), pemerintah memberikan kesempatan kepada masyarakat untuk memanfaatkan sertipikat tanah. Dimana masyarakat diberi kemudahan untuk meminjam uang di bank untuk kegiatan usaha dengan jaminan sertipikat tanah (Undang-Undang nomor 19 tahun 2013). Undang-undang ini memberikan kebebasan pada petani untuk mengembangkan usaha pertanian melalui bantuan pembiayaan dengan harapan agar petani dapat berdaya secara ekonomi. Kebijakan ini kemudian di perkuat Peraturan Presiden nomor 86 tahun 2018 khususnya pasal 16 ayat 8 yang menyatakan bahwa fasilitasi akses permodalan dilakukan melalui penetapan kebijakan pemberian pinjaman kepada kelompok sasaran dengan penataan aset dengan bunga rendah dengan jangka waktu panjang. Penataan aset dilakukan melalui redistribusi tanah pertanian dan nonpertanian, sedangkan legalisasi aset dilakukan melalui sertipikasi tanah. Tentunya tidaklah cukup diberi sertipikat tanah untuk dapat meningkatkan kesejahteraan petani melainkan melalui dukungan atau upaya-upaya lain.

Ini berarti petani perlu dilindungi dan diberdayakan agar kesejahteraannya tercapai, Adanya pemberdayaan petani oleh pemerintah bertujuan antara lain untuk mewujudkan kemandirian. Namun demikian upaya untuk mewujudkan tujuan pemberdayaan petani tersebut tidak semudah yang direncanakan. Berbagai kerumitan dan tantangan dalam pemberdayaan mulai dari partisipasi, akuntabilitas publik, hingga pada kapasitas kelembagaan dalam memberdayakan masyarakat. Sebagaimana temuan Astuti (2015) bahwa pemberdayaan yang selama ini dilakukan untuk masyarakat Desa Asmorobangun Kota Kediri dari proses pemberdayaan cukup baik, namun yang perlu ditingkatkan adalah ketersediaan aktor pendamping bagi petani dan keberlanjutan kegiatan. Faktor penghambat tersebut dapat teratasi dengan memaksimalkan sumber daya dan faktor pendukung yang lainnya yang dimiliki oleh masyarakat. Fakta empiris lain yaitu temuan Supardjan (2012) bahwa program pembiayaan mikro yang dilakukan oleh Koperasi Baitul Ikhtiar (BAIK) yang menemukan tahapan pemberdayaan belum sepenuhnya dipahami sebagai proses dalam konteks teoritik pemberdayaan masyarakat. Mulai dari tahap pemilihan wilayah sasaran sampai pada tahap evaluasi belum sejalan dengan tahapan pemberdayaan..Selain itu penyaluran pembiayaan belum banyak digulirkan untuk usaha produktif. Lain halnya penelitian Teturan \& Tajuddin (2015) bahwa pemberdayaan masyarakat dalam RESPECT di Desa Jayakuprik dan Desa Semangga telah dilakukan sesuai dengan pedoman program. Program terus dilakukan sehingga mampu mengatasi masalah yang ada di masyarakat. Keseluruhan program sangat bermanfaat karena orang bisa merasakan dampak langsung dari program tersebut. Artinya bahwa terjadi gap empirik dalam program pemberdayaan masyarakat, dimana disatu pihak program pemberdayaan berjalan dengan baik di lain pihak pemberdayaan terlaksana namun tidak berkontribusi positif bagi masyarakat.

$\mathrm{Hal}$ ini relevan dengan data awal penelitian di desa Lasembangi, Kecamatan Lasalimu, Kabupaten Buton bahwa selain kurangnya partisipasi, masalah lain dalam program pemberdayaan masyarakat petani di Kecamatan Lasalimu, khususnya di desa Lasembangi adalah kapasitas kelembagaan yang terkait dengan kesiapan lembaga pemberi modal usaha. Secara kelembagaan pemberi modal siap untuk membantu pemberdayaan masyarakat petani, namun niat baik tersebut tidak di dukung oleh upaya yang cukup. Masyarakat petani harus ke kota untuk mengurus kredit usaha tani atau modal usaha, sedangkan lembaga pemberi bantuan belum membangun unit-unit badan layanan kredit di pedesaan. Sehingga warga kesulitan untuk memanfaatkan sertipikat tanah sebagai modal. Kondisi ini berdampak kemiskinan petani, oleh karena itu perlu pemberdayaan petani. 
Pada prinsipnya, kapasitas kelembagaan faktor penting dalam mengatasi berbagai masalah pembangunan yang bersentuhan langsung dengan masyarakat. Chalid (2005) mengatakan bahwa kapasitas kelembagaan pemberdayaan masyarakat dalam pembangunan menjadi faktor penting terutama dalam pembangunan yang berkeadilan dan menyentuh kepentingan rakyat banyak. Kapasitas kelembagaan sendiri dapat diartikan sebagai tingkat kemampuan dari keseluruha elemen baik dalam pola-pola hubungan di dalam organisasi tersebut atau berbagai bentuk aktivitas didalamnya untuk dapat mencapai tujuan organisasi tersebut dengan efektif, efisien dan berkelanjutan.

Penelitian terdahulu tentang pentingnya kapasitas kelembagaan dalam pemberdayaan masyarakat antara lain dikemukakan Sukarno (20II) yang menyatakan bahwa kapasitas kelembagaan melalui penguatan lembaga masyarakat dengan pendekatan pengembangan kawasan dapat menjamin peningkatan kesejahteraan masyarakat pesisir yang antara lain ditunjukkan dengan peningkatkan kualitas sumber daya manusia dan prasarana secara merata di daerah pesisir di Jawa Timur. Kurniyati (2013) menemukan bahwa pentingnya kapasitas kelembagaan melalui rumusan strategi dan program penguatan kapasitas kelembagaan Kelompok dalam pengembangan ekonomi lokal di wilayah kota Yogyakarta. Penguatan kapasitas ditunjukkan dengan peningkatkan kinerja pengurus dan peningkatkan kesadaran seluruh anggota dalam membenahi manajemen pengelolaan usaha dengan cara. Juga terdapat penguatan economic capital, yaitu dengan meningkatkan modal lembaga dan Penguatan human capital dan social capital. Kapasitas kelembagaan juga diperlukan dalam organisasi pelayanan publik antara lain dijelaskan Fatimah (2019) dimana kapasitas kelembagaan menjadi alat yang digunakan untuk memperkuat aspek internal organisasi dimana terdapat tujuh elemen utama yang memiliki ketergantungan satu sama lain, artinya perubahan satu elemen akan mempengaruhi elemen lainnya. Tujuh unsur penting yaitu adanya aspirasi, strategi, keterampilan organisasi, sumber daya manusia, system dan infrastruktur, struktur organisasi dan budaya. Mengacu pada konteks penelitian di atas maka peneliti tertarik untuk meneliti dengan topik pemberdayaan masyarakat petani penerima sertipikat tanah melalui program kredit usaha tani di Kecamatan Lasalimu Kabupaten Buton.

Pemberdayaan masyarakat merupakan upaya meningkatkan kemampuan masyarakat agar dapat hidup mandiri dan berkelanjutan. Pemberdayaan masyarakat dalam konteks administrasi publik orientasinya bukan pada kegiatan ekonomi melainkan proses administrasi pemberdayaan masyarakat yaitu proses pemberdayaan itu sendiri. Penelitian ini tidak ditujukan utnuk menjelaskan semua aspek yang terkait dengan proses pemberdayaan masyarakat misalnya Narayan (2002) yang menjelaskan bahwa pemberdayaan masyarakat terdiri dari aspek partisipasi , akuntabilitas, akses informasi dan kapasitas kelembagaan. Penelitian ini hanya difokuskan pada dimensi kapasitas pemerintah daerah (lembaga terkait) yaitu kemampuan pemerintah dan masyarakat petani untuk bekerja bersama, mengorganisir individu petani dan kelompok-kelompok yang ada di dalamnya, memobilisasi sumber-sumber daya yang ada untuk menyelesaikan masalah bersama (ketidakberdayaan). Sebagaimana dijelaskan di atas, pemberdayaan akan memiliki kekuatan dan keberlanjutan jika memiliki kapasitas kelembagaan yang baik.

\section{METODOLOGI}

Berangkat dari topik penelitian, maka desain penelitian ini menggunakan desain kualitatif deskriptif. Menurut Steven Dukeshire \& Jenifer Thurlow dalam (Sugiyono 2017) penelitian kualitatif berkenaan dengan data yang bukan angka, mengumpulkan dan menganalisis data yang bersifat naratif. Metode kualitatif yang naturalistik memungkinkan evaluator dan 
para pemangku kepentingan (stakeholders)

berinteraksi sosial secara horizontal dalam suasana yang lebih humais, dinamis, dan intensif terbebas dari sekat-sekat sosial artifisial yang kaku. Alasan penelitain ini menggunakan kualitatif deskriptif yaitu adanya permasalahan atau isu yang perlu di eksplorasi, kebutuhan untuk memahami yang lebih detail dan lengkap tentang kapasitas kelembagaan pemberdayaan masyararakat petani penerima sertipikat tanah melalui progran kredit usaha tani, sehingga ingin memahami konteks lingkungan bagaimana kapasitas kelembagaan dan lebih cocok menggunakan metode kualitatif, (Creswell, 2014). Dalam penelitian ini peneliti merupakan orang yang paling berperan. Alasanya adalah segala sesuatunya belum mempunyai bentuk yang pasti. Masalah, fokus penelitian, prosedur penelitian, hipotesis yang digunakan, bahkan hasil yang diharapkan.

Sumber data dalam penelitian ini adalah wawancara, observasi dan studi dokumentasi. Peneliti melakukan wawancara, pengamatan dan studi dokumentasi atas peristiwa yang terjadi di desa Lasembangi, berupa usaha petani dalam pemperoleh modal usaha, memanfaatkan modal usaha, dan keadaan petani dalam proses pemberdayaan dan fenomena lain yang terkait sehingga didapatkan penjelasan kapasitas kelembagaan secara keseluruhan. Teknik analisis data dalam penelitian ini dilakukan dengan tiga strategi; pertama, menyiapkan dan mengorganisasikan data (yaitu data teks seperti transkrip atau data gambar seperti foto) untuk dianalisis kedua, mereduksi data dan terkahir (ketiga), menyajikan data. Data yang disajikan mengacu pada informasi dari hasil wawancara, observasi dan dokumentasi. Data tersebut dielaborasi dari berbagai informasi yang diperoleh dari informan.

\section{HASIL DAN PEMBAHASAN}

Dalam proses pemberdayaan masyarakat diperlukan kapasitas yang kuat dari suatu institusi dalam mengelola semua sumber daya yang ada. Kapasitas kelembagan dalam pemberdayaan terkait dengan kemampuan organiasai atau orang untuk bekerja bersama, mengatur diri mereka sendiri, dan memobilisasi sumber daya untuk memecahkan masalah yang menjadi kepentingan bersama. Pengelolaan sumber daya institusi dilakukan dengan memberdayakan segala potensi yang ada untuk mencapai tujuan yang hendak dicapai.

Program pemberdayaan masyarakat tani melalui program sertifikasi tanah secara kelembagan mendorong masyarakat untuk memanfaatkan sertipikat tanah untuk modal pengembangan pertanian masyarakat, sebagaimana yang disampaikan Kepala Kantor Pertanahan Kabuten Buton bahwa kemampuan pemerintah dalam mengorganisir masyarakat untuk memanfaatkan sertipikat tanah untuk modal pengembangan pertanian masyarakat sudah cukup baik, terbukti dengan sudah ada beberapa masyarakat yang memanfaatkan sertipikat tanahnya untuk modal usaha. Sebagai kantor yang melakukan pendataan kepemilikan bidang tanah dan sertifikasi tanah, Kantor Pertanahan Kabupaten Buton telah mensertifikasi tanah dan sertipikat tersebut dimanfatkan masyarakat untuk pengajuan permohonan usaha kepada pihak perbankan. Tentunya secara kelembagaan sektor publik secara kapasitas selalu siap untuk diberdayakan. Organisasi sektor publik dapat memanfaatkan segala kemampuan guna mewujudkan program yang hendak dicapai.

Kemampuan sumber daya dalam pelayanan proses pemberdayaan masyarakat dengan memanfaatkan sertipikat tanah juga diceritakan kepala Desa Lasembangi yang menyatakan Desa Lasembangi telah mengorganisir semua potensi yang dimiliki dalam rangka memberikan bantuan pada masyarakat pada program-program pemberdayaan masyarakat petani. Pemerintah desa memberikan rekemondasi kepada 
pihak perbankan agar masyarakat yang memiliki sertipikat tanah diberikan bantuan untuk usaha maupun pertanian. Informasi relefan juga disampaikan sekretaris Desa Lasembangi yang menyatakan telah memberikan dukungan kepada petani untuk mengembangan hasil pertanianya, olehnya itu bila ada petani yang mengajukan permohonan bantuan pendanaan untuk pertanian atau usaha di Desa, pemerintah desa memberikan surat keterangan sebagai syarat masyarakat memperoleh bantuan kredit usaha tani. Pemberian bantuan tersebut biasanya dengan jaminan sertipikat tanah.

Berdasarkan dokumen pemerintah Desa Lasembangi, dimana pemerintah desa telah mengeluarkan puluhan surat keterangan usaha untuk masyarakat petani. Dengan surat tersebut pihak perbankan dapat memproses permohonan masyarakat. dari penelurusan dokumen diperoleh data permohonan bantuan. Data menunjukan banyak warga Desa Lasembangi yang megajukan permohonan bantuan pinjaman baik untuk usaha pertanian maupun usaha jual beli sembako. Sejumlah 44 orang warga yang menjaminkan sertipikat tanah untuk tujuan usaha baik pertanian maupun usaha lainnya. Artinya pemberdayaan masyarakat melalui program sertifikasi tanah dilaksanakan dengan memanfaatkan semua potensi yang dimiliki baik oleh masyarakat maupun pemerintah. Banyaknya masyarakat yang menerima bantuan KUR merupakan wujud bahwa kapasitas kelembagaan dalam proses pemberdayaan masyarakat diorganisir dengan baik.

Namun demikian kapasitas kelembagaan bukan hanya sebatas mengorganisir potensi lembaga yang terlibat dalam proses pemberdayaan, melainkan hubungan atau koordinasi antar lembaga yang terkait. Sebagaimana yang diceritakan kepala Kantor Pertanahan Kabupaten Buton yang menyatakan bahwa kerjasama pemerintah dengan masyarakat dalam program pemberdayaan masyarakat tani masih kurang, baik itu komunikasi antara masyarakat dengan pemerintah baik Dinas Pertanian maupun dengan pihak bank, sehingga seakan-akan masyarakat memanfaatkan modal usahanya tanpa pendampingan.

Informasi diatas menunjukan dibalik keberhasilan mengorganisir sumber daya organisasi terdapat kelemahan dalam mengkomuikasikan program pemberdayaan masyarakat petani. Masalah ini terletak pada proses setelah pemberian bantuan baik uang maupun bibit pertanian. Proses yang dimaksud adalah pendampingan terhadap masyarakat yang tidak terkoneksi antara satu lembaga dengan lembaga yang lainnya. Pemberdayaan masyarakat petani berjalan secara mandiri oleh masyarakat sedangkan fungsi pendampingan dan penyuluhan yang melibatkan lembaga terkait tidak berjalan.

Pada sisi lain, Pemerintah Desa Lasembangi sebagai yang paling bersentuhan langsung dengan masyarakat menjelaskan bahwa pemerintah Desa telah mengorganisir kapasitasnya dalam mendorng pemeberdayaan masyarakat petani. Pemerintah desa sangat berperan aktif dengan menghubungkan individu maupun kelompok tani dengan menginventaris segala kebutuhan petani untuk dapat disampaikan kepada Dinas Pertanian, dan juga memberi kemudahan dalam pengurusan syarat-syarat untuk mendapatkan KUR dari pihak Bank. Sumber dari pemerintah desa tersebut menggambarkan adanya upaya pemerintah desa untuk memberdayakan masyarakat tani dengan berkoordinasi dengan dinas pertanian, namun tidak dengan Dinas pertanian dengan pihak perbankan dan kantor pertanahan. Koordinasinya lebih pada satu arah sehingga program pemberdayaan petani tidak terkoneksi dengan baik. penyuluhan dan pendampingan hanya sebatas dinas tertentu tetapi tidak ada komitmen bersama secara formal untuk memberdayakan masyarakat petani di Desa Lasembangi.

$\mathrm{Hal}$ ini sebagimana yang diceritakan oleh Kepala kantor pertanahan Kabupaten Buton bahwa kantor pertanahan telah memberdayakan semua kapasitas yang dimiliki yaitu dengan melaksanakan program PTSL 
di Desa Lasembangi. Dinas Pertanian melakukan pendampingan dan pemberian bantuan pertanian. Perbankan mempermudah syarat dalam pengambilan KUR. Informasi diatas menunjukan pemberdayaan masyarakat berjalan tidak secara lintas sektoral, namun sesuai kewenangn masing-masing. Lembaga terkait dengan kemampuan yang dimiliki ikut serta proses pemberdayaan masyarakat petani namun sesuai dengan visi dan misi atau program masing-masing. Sedangkan Dinas Pertanian Kabupaten Buton menyatakan telah memberikan bantuan terhadap masyarakat berupa alat, pupuk dan obat-obatan untuk pertanian. Selain itu pemberdayaan masyarakat petani terkendala pada sinergitas antara lembaga yang bertanggungjawab. Namun menurut seorang staf dinas pertanian mengemukakan ada kendala dalam proses pemberdayaan masyarakat tani yaitu kurangnya para petugas penyuluh pada dinas pertanian. Dismping itu, belum ada sinergitas yang baik antara para pihak baik kantor Pertanahan, Dinas Pertanian, dan pihak perbankan.

Selain keterbatasan sumberdaya manusia (penyuluh) juga terdapat kendala lain dalam proses pemberdayaan yaitu masalah akses yang masih jauh dan jaringan yang belum memadai. Akses ke Desa Lasembangi yang cukup jauh dan jaringan komunikasi yang belum ada. Dalam mengatasi masalah tersebut pihak pemberi pinjaman memberikan alternatif yang memungkinkan pemberian KUR berjalan baik yaitu dengan cara menyebarkan brosur-brosur dan membuka cabang BRI link di desa tetangga yaitu Desa Kamaru. Mengacu pada temuan diatas menunjukan bahwa kapasitas kelembagan dalam pemberdayaan masyarakat petani belum terorganisir dengan baik dan belum terjalin kerjasama yang terintegrasi antara Kantor Pertanahan Kabupaten Buton, Dinas Pertanian, pemerintah Desa dan pihak perbankan. Kelembaga terkait masih berjalan sendiri-sendiri dalam program pemberdayaan masyarakat tani. Sehingga masalah ketidakberdayaan masih melekat pada sebagian petani Desa Lasembangi.
Temuan tersebut menggambarkan program program pemberdayaan masyarakat petani yang tidak terorganisir dengan baik. Temuan lain menunjukan banyak proyek yang telah berakhir tidak dapat dipertahankan oleh anggota masyarakat karena tingkat pemberdayaan yang rendah (Sianipar et al., 20I3). Ego sektoral nampaknya masih menghiasi praktek pemberdayaan masyarakat. Dalam kondisi keterbatasan atau ketidakberdayaaan masyarakat petani harusnya tidak muncul ego sektoral. Elemen atau unsur pemberdayaan masyarakat petani, perlu membangun koordinasi lintas sektoral sehingga apa yang menjadi kebutuhan petani dalam pemberdayaan dan di pertanggungjawabkan. Pemangku kepentingan pemberdayaan hendaknya mengorganisir semua potensi yang dimiliki untuk memberdayakan masyarakat petani, karena dengan perorganisasi sumber daya yang baik akan berdampak baik pula dalam proses pemberdayaan. Speer dan Hughey dalam (Sianipar et al., 2013) menyimpulkan bahwa pengorganisasian masyarakat merupakan cara penting untuk mencapai pemberdayaan. Mereka menyatakan erat kaitannya dengan ekologi masyarakat lokal, bagaimana pihak luar harus memperhatikan kondisi psikologis masyarakat untuk mencapai kekuatan sosial sebagai pendahulu pemberdayaan.

Lingkungan masyarakat petani pedesaan pada biasanya lebih mudah untuk diorganisir dalam program pengembangan masyarakat. Masyarakat petani juga sering antusias ketika program-program pemberdayaan menyentuh kebutuhan dasar mereka, namun sebaliknya jika tidak menyentuh kebutuhan dasar mereka cenderung apatis dalam kegiatan pemberdayaan. Pemerintah khususnya Dinas terkait harusnya membangun program bukan pada pendekatan projek melainkan berbasis kebutuhan dan jangka panjang. Projek pemberdayaan masyarakat tani misalnya, dilakukan dengan terencana, terarah, terstruktur dan sistematis. Terarah pada tujuan yang hendak dicapai, terencana artinya secara bertahap program 
pemberdayaan dilaksanakan, hingga dilakukan evaluasi bersama.

Kegagalan pemberdayaan selama ini karena pola pemberdayaan yang terpecah antara satu lembaga dengan lembaga yang lainnya. Selain itu evaluasi program pemberdayaan yang cenderung tidak dilakukan, sehingga tidak mengetahui apa yang telah dicapai atas pemberdayaan masyarakat tani. Masyarakat petani juga cenderung lalai untuk memperhatikan mengapa program yang mereka kerjakan tidak berkualitas dan tidak berkelanjutan.

Pemberdayaan masyarakat petani melalui program sertifikasi tanah, perlu kerjasama antara Kantor Pertanahan, pihak perbankan dan masyarakat yang dibangun secara formal dalam satu kesatuan. Perlunya penyatuan ini karena program pemberdayaan berjalan secara sepihak antara lembaga-lembaga terkait. Masingmasing berjalan dengan programnya tanpa ada komunikasi. Rendahnya niat baik antara lembaga yang terlibat dalam pemberdayaan untuk berkerjasama menambah sulitnya program pemberdayaan.

Kondisi egosektoral yang masih melekat pada Dinas dan lembaga terkait merupakan tanggungjawab pemerintah sebagai penerima mandat dari masyarakat untuk melaksanakan pelayanan publik. Pemerintah sebagai aktor yang paling berperan dalam program pemberdayaan harus memahmi kondisi pemberdayaan yang selalu gagal atau berhasi dalam jangka pendek namun gagal dalam jangka panjang.

Proses pemberdayaan lebih dilakukan secara intens dan berkelanjutan, dengan melibatkan berbagai stakehoders. Selain itu perlu memperhatikan tata kelola pemberdayaan masyarakat, karena sebaik apapun program yang diluncurkan pemerintah tanpa tata kelola yang baik, hanya akan menghasilkan sekelompok kegagalan program, program yang mandek, sehingga semakin menambah beban pemerintah dan lebih-lebih masyarakat miskin. Memberdayakan masyarakat itu lebih penting ketimbang mengembangkan masyarakat. Masyarakat berkembang secara aspek sosial dan ekonomi belum tentu mereka dapat berdaya, namun masyarakat yang berdaya sudah barang tentu telah berkembang. Masyarakat yang berdaya dalam konteks pemberdayaan juga harus diperhatikan keberlangsunganya.

\section{KESIMPULAN}

Kapasitas kelembagan dalam pemberdayaan masyarakat petani belum terorganisir dengan baik dan belum terjalin kerjasama yang terintegrasi antara Kantor Pertanahan Kabupaten Buton, Dinas Pertanian, Pemerintah Desa dan Pihak Perbankan. Kelembagaan terkait masih berjalan sendiri-sendiri dalam program pemberdayaan masyarakat tani. Sehingga masalah ketidakberdayaan masih melekat pada sebahagian petani Desa Lasembangi.

Saran atau implikasi penelitian ini adalah diperlukan evaluasi kapasitas kelembagan dalam pemberdayaan masyarakat agar tidak terjadi egosektoral. Para pemangku kepentingan, harus menyadari bahwa dalam proses pemberdayaan masyarakat diperlukan kapasitas yang kuat dari suatu institusi dalam mengelola semua sumber daya yang ada. Kapasitas kelembagan yang dimaksud terkait dengan kemampuan organiasai atau orang untuk bekerja bersama, dan memobilisasi sumber daya untuk memecahkan masalah yang menjadi kepentingan bersama. Jika tidak ada perhatian yang kuat pada hal ini maka akan berkonsekuensi pada daya tahan dan bahkan keberlanjutan pemberdayaan itu sendiri. Penelitian selanjutnya tentang pemberdayaan mesti memperdalam aspek kapasitas kelembagaan dengan mengacu pada penggunaan satu teori ataupun kombinasi teori yang relevan yang dielaborasi secara kualitatif. 


\section{REFERENSI}

Chalid, P. (2005). Otonomi Daerah: Masalah, Pemberdayaan, dan Konflik. Kemitraan, I-I55.

Creswell, J. W. (20|4). Penelitian Kualitatif \& Desain Riset. (Ketiga.). Pustaka Pelajar, Terjemahan.

Denhardt, J., \& Denhardt, R. (20I3). Pelayanan Publik Baru: Dari Manejemen Steering ke Serving. In Kreasi Wacana. Kreasi Wacana.

Didi, L. (2018). Pemberdayaan masyarakat desa pesisir melalui program manajemen rehabilitasi terumbu karang dalam perspektif governance di Kabupaten Buton Selatan. Universitas Brawijaya.

Fatimah, A. S. (2019). Kapasitas Kelembagaan Dinas Pengendalian Penduduk, Keluarga Berencana, Pemberdayaan Perempuan Dan Perlindungan Anak Kota Tasikmalaya. Jurnal Administrasi Dan Kebijakan Publik, 4(I).

Keban, Y. T. (20I4). Enam Dimensi Strategis Administrasi Publik (Edisi 3). Penerbit Gava Media.

Kurniyati, Y. (20I3). Penguatan Kapasitas Kelembagaan Kelompok Pew Untuk Pengembangan Ekonomi Lokal Kota Yogyakarta. Jurnal Maksipreneur, III(I).

Lifa Indri Astuti., H. \& M. R. (20I5). Pemberdayaan Masyarakat Dalam Pembangunan Pertanian Berkelanjutan (Studi Pada Desa Asmorobangun Kecamatan Puncu Kabupaten Kediri). Jurnal Administrasi Publik Mahasiswa Universitas Brawijaya, 3(II), 1886-1892.

Narayan, D. (2002). Empowerment and Poverty Reduction. World Bank.

Reforma Agraria, Pub. L. No. 86 (2018).

Sianipar, C. P. M., Yudoko, G., Adhiutama, A., \& Dowaki, K. (2013). Community Empowerment through Appropriate Technology: Sustaining the Sustainable Development. Procedia Environmental Sciences, 17 , 1007-1016. https://doi.org//0.1016/j.proenv.2013.02.120

Sugiyono. (2017). Metode Penelitian Kebijakan Pendekatan Kuantitatif, Kualitatif, kombinasi, R\&D dan Penelitian Evaluasi. Alfabeta.
Sukarno, H. (20II). PENGUATAN KELEMBAGAAN MASYARAKAT PESISIR DI JAWA TIMUR. SAINTEK Jurnal Sains, Teknologi Dan Profesi Akademi Angkatan Laut, 3.

Sulistiyani, A. T. (2017). Kemitraan dan Model-Model Pemberdayaan. Gava Media.

Supardjan, M. S. (20I2). Pemberdayaan masyarakat Pada Program Pembiayaan mikro (studi tetang pelaksanaan program pembiayaan mikro pada Anggota Koperasi Baytul Ikhtiar Kabupaten Bogor-Jawa Barat). Universitas Indonesia.

Teturan, Y. E., \& Tajuddin, M. A. (20I5). Analysis of the Role of the Community Empowerment Program in Strategic Plan Development Village at Semangga District of Merauke. Journal of Public Administration and Governance, 5(3), 180. https://doi.org// 0.5296/jpag.v5i3.8375

Undang-Undang Republik Indonesia. (2003). UndangUndang Republik Indonesia Nomor 19 Tahun 2003 Tentang Perlindungan dan Pemberdayaan Petani. 